\title{
Detection and Quantification of Vitamins in Microliter Volumes of Biological Samples by LC-MS for Clinical Screening
}

\author{
Maryam Khaksari (ㅁ) and Lynn R. Mazzoleni 다 \\ Chemical Advanced Resolution Methods (ChARM) Laboratory, Michigan Technological University, Houghton, Michigan, 49931 \\ Dept. of Chemistry, Michigan Technological University, Houghton, Michigan, 49931 \\ Chunhai Ruan \\ Metabolomics Core, University of Michigan Medical School, Ann Arbor, Michigan, 48105 \\ Peng Song, Neil D. Hershey, and Robert T. Kennedy \\ Dept. of Chemistry, University of Michigan, Ann Arbor, Michigan, 48109 \\ Mark A. Burns \\ Dept. of Chemical Engineering, University of Michigan, Ann Arbor, Michigan, 48109
}

Adrienne R. Minerick* (1)

Dept. of Chemical Engineering, Michigan Technological University, Houghton, Michigan, 49931

DOI 10.1002/aic.16345

Published online July 10, 2018 in Wiley Online Library (wileyonlinelibrary.com)

\begin{abstract}
A method for simultaneous determination of water-soluble vitamins $B_{1}, B_{2}, B_{3}$ (nicotinamide), $B_{5}, B_{6}$ (pyridoxamine), $B_{9}$ and fat-soluble vitamins $E$ ( $\alpha$-tocopherol) and $K_{1}$ in tears, and $B_{1}, B_{2}, B_{3}, B_{5}, B_{6}, B_{9}, A$ (retinol), and $E$ in blood serum is described. Liquid chromatography-mass spectrometry (LC-MS) was used with a ternary mobile phase of water and acetonitrile containing $0.1 \%$ formic acid and methanol containing $5 \mathrm{mM}$ ammonium formate. Vitamins were quantified using an internal standard method. Using $25 \mu \mathrm{L}$ injection volumes, the limits of detection were in the range of 0.066-5.3 $\mathrm{ng}$ in tear, and 0.087-1.1 $\mathrm{ng}$ in serum with linear responses for all vitamins. Intra- and inter-day precision and recoveries were satisfactory. This is the first study to demonstrate simultaneous vitamin detections in microliters of biological samples which has distinct advantages in many diagnostic applications with limited available fluids (e.g., tears; elderly anemic blood) or sampling small subjects (e.g., rodents). (C) 2018 American Institute of Chemical Engineers AIChE J, 64: 3709-3718, 2018

Keywords: tear, blood serum, LC-MS, water-soluble vitamins, fat-soluble vitamins
\end{abstract}

\section{Introduction}

Essential biochemical functions of vitamins in the human body include important roles in protein metabolism, maintenance of blood glucose levels, regulation of cell growth, and cell differentiation. ${ }^{1}$ Thirteen different vitamins are currently recognized by the $\mathrm{USDA}^{2}$ and are classified into two groups according to their solubility; water-soluble vitamins include all B vitamins and vitamin $\mathrm{C}$ whereas the fat-soluble vitamins include vitamins $\mathrm{A}, \mathrm{D}, \mathrm{E}$, and $\mathrm{K}$. Water-soluble vitamin deficiencies can cause permanent tissue damage and debilitating effects in humans while fat-soluble vitamins assist in anabolic and catabolic pathways in the body and are a current source of interest to nutritionists and clinicians.

All living tissues require vitamins and nutrients. The cornea is the outermost, transparent layer of living cells in the eye

\footnotetext{
Additional Supporting Information may be found in the online version of this article.

Correspondence concerning this article should be addressed to A. R. Minerick at minerick@mtu.edu.
}

(C) 2018 American Institute of Chemical Engineers that helps focus light and protect the complex network of nerves and tissues in the eye. ${ }^{3}$ The metabolism of the cornea requires a constant supply of amino acids, vitamins, and other nutrients; no blood vessels extend to the cornea, ${ }^{3,4}$ so tears likely supply these nutrients. Previously we demonstrated the determination of water-soluble vitamins $\mathrm{B}_{1}, \mathrm{~B}_{2}, \mathrm{~B}_{3}, \mathrm{~B}_{5}$, and $\mathrm{B}_{9}$ and fat-soluble vitamin $\mathrm{E}$ in tears and blood serum via two separate LC-MS methods. ${ }^{5,6}$

Water-soluble and fat-soluble vitamins have diverse chemical structures and properties, making their determination from a single chromatography assay challenging. ${ }^{7}$ Previously reported vitamin detection methods predominantly focused on determining individual vitamins or a subset of vitamins with similar polarities. For example, HPLC methods exist for a subset of water-soluble vitamins in blood serum, multivitamin tablets, and food. ${ }^{8-11}$ HPLC assays for several fat-soluble vitamins in blood serum, tablets, and daily products have been reported as well. ${ }^{12-17}$ There are also methods for simultaneous extraction of water-soluble and fat-soluble vitamins except they eventually used separate analytical methods for analysis. ${ }^{18,19}$ Although simultaneous detection of water-soluble and fat-soluble vitamins in a single chromatography run from a 
single aliquot of sample has been reported, these methods are only reported to determine vitamin contents in uncomplicated, non-biological matrices, such as pharmaceutical preparations, $^{20-23}$ foodstuff, ${ }^{20,22,24,25}$ and beverages. ${ }^{26}$ The method by Ferreiro-Vera et al. ${ }^{27}$ was able to determine only two vitamins with different polarities in the blood serum while unified supercritical fluid and liquid chromatography method by Taguchi et al. ${ }^{28}$ was only validated with standard solutions. Determination of tear vitamins $A,{ }^{29,30} \mathrm{D},{ }^{31}$ and $\mathrm{C}^{32,33}$ are also separately reported in the literature. To date, no simultaneous vitamin detection method is available for extraction and detection of multiple vitamins with different polarities from biological samples.

In this article, we report a new, ternary solvent LC method using electrospray ionization (ESI) mass spectrometry for the identification and quantification of water-soluble and fatsoluble vitamins. The present LC-MS method is able to capture all seven $\mathrm{B}$ vitamins and five fat-soluble vitamins (including two forms of vitamins $\mathrm{D}$ ); while $\mathrm{B}_{1}, \mathrm{~B}_{2}, \mathrm{~B}_{3}$ (nicotinamide), $\mathrm{B}_{5}$, $\mathrm{B}_{6}$ (pyridoxamine), $\mathrm{B}_{9}, \mathrm{~A}$ (retinol), and $\mathrm{E}$ ( $\alpha$-tocopherol) were successfully detected in blood serum and $\mathrm{B}_{1}, \mathrm{~B}_{2}, \mathrm{~B}_{3}$ (nicotinamide), $\mathrm{B}_{5}, \mathrm{~B}_{9}, \mathrm{E}$ ( $\alpha$-tocopherol), and $\mathrm{K}_{1}$ were successfully detected in human tear samples.

To improve upon assays that only measure a subset of vitamins, this combined method was developed using commonly available and robust analytical tools to provide a more complete nutritional status with reduced material and chemical demands, reduced instrument preparation and run times, smaller sample volumes, and shortened active technician time. Furthermore, small sample requirements improve the ability to detect vitamins in infants, sample limited situations (e.g., tears), elderly patients, or those with anemia. This article describes the methodology used in a larger clinical study. Results from an extension of this method applied to tears and blood serum of 45 infant/parent pairs will be published in a subsequent article. Here, we describe the technical aspects of the combined analytical strategy, which enables simultaneous determination of most water-soluble and fat-soluble vitamins without the need for separate assays.

\section{Materials and Methods}

\section{Materials and chemicals}

The purchased standard water-soluble and fat-soluble vitamins were: thiamine hydrochloride (reagent grade, $\geq 99 \%$, HPLC), (-)-riboflavin ( $\geq 98 \%$ ), nicotinamide ( $\geq 98 \%$, TLC), D-pantothenic acid hemicalcium salt ( $\geq 98 \%$, TLC), pyridoxamine dihydrochloride ( $\geq 98 \%$ ), biotin ( $\geq 99 \%$, TLC), folic acid ( $\geq 97 \%$ ), retinol (synthetic, $\geq 95 \%$ [HPLC], crystalline), cholecalciferol (pharmaceutical secondary standard), 25-hydroxycholecalciferol ( $\geq 98 \%$, HPLC), $( \pm \alpha)$-tocopherol (pharmaceutical secondary standard), and phylloquinone (analytical standard) from SigmaAldrich (St. Louis, MO). Vitamin metabolites were selected based on the clinical assays ${ }^{34,35}$ and availability in biological samples $^{36,37}$ (details in Supporting Information Section 2).

Stable isotope internal standards (IS) of vitamins $\mathrm{B}_{1}$ (thiamine[4-methyl- ${ }^{13} \mathrm{C}$-thiazol-5-yl- ${ }^{13} \mathrm{C}_{3}$ ] hydrochloride), $\mathrm{E}$ ( $\alpha$-tocopherol[ring-5,7-dimethyl- $\left.\left.\mathrm{d}_{6}\right]\right)$, and $\mathrm{K}\left(5,6,7,8-\mathrm{d}_{4}, 2\right.$-methyl- $\left.\mathrm{d}_{3}\right)$ were purchased from Sigma-Aldrich (St. Louis, MO). Stable isotopes of vitamins $B_{2}$ (riboflavin- $\left[{ }^{13} \mathrm{C}_{4},{ }^{15} \mathrm{~N}_{2}\right]$ ), $\mathrm{B}_{5}$ (calcium pantothenate$\left.\left[{ }^{13} \mathrm{C}_{3},{ }^{15} \mathrm{~N}\right]\right)$, biotin- $\left[\mathrm{d}_{2}\right]$, and $\mathrm{D}_{3}-\left[6,19,19-\mathrm{d}_{3}\right]$ were purchased from Isosciences (Trevose, PA) and $\mathrm{B}_{3}$, nicotinamide-[2,4,5,6,- $\left.\mathrm{d}_{4}\right]$ and $A$ (retinol- $\left[\mathrm{d}_{5}\right]$ ) were purchased from $\mathrm{C} / \mathrm{D} / \mathrm{N}$ isotopes (PointeClaire, Quebec, Canada) and ALSACHIM (Illkirch Graffenstaden, France), respectively. LC-MS grade methanol $(\mathrm{MeOH})$, acetonitrile (ACN), acetone, formic acid (FA), ammonium formate, dimethyl sulfoxide (DMSO), butylated hydroxytoluene (BHT), and $99.99 \%$ deuterium oxide $\left(\mathrm{D}_{2} \mathrm{O}\right)$ were also purchased from Sigma-Aldrich (St. Louis, MO). Water was purified using a Thermo UV/UF ultrapure water system (Waltham, MA).

\section{Standard solutions for calibration curves}

Stock solutions of $5 \mathrm{mM}$ thiamine, nicotinamide, pantothenic acid, and pyridoxamine in water and riboflavin, biotin, and folic acid in DMSO were prepared in glass containers and stored at $-20^{\circ} \mathrm{C}$. Solutions of $50 \mathrm{mM}$ retinol, cholecalciferol and $\alpha$-tocopherol, $5 \mathrm{mM} 25$-hydroxycholecalciferol, and $25 \mathrm{mM}$ of phylloquinone in $\mathrm{MeOH}$ were stored in liquid nitrogen at $-196^{\circ} \mathrm{C}$. IS stock solutions were $10 \mathrm{mM}$ thiamine-[4-methyl $-{ }^{13} \mathrm{C}$ thiazol-5-yl- $\left.{ }^{13} \mathrm{C}_{3}\right]$ hydrochloride, $2 \mathrm{mM}$ riboflavin- $\left[{ }^{13} \mathrm{C}_{4},{ }^{5} \mathrm{~N}_{2}\right]$, $25 \mathrm{mM}$ nicotinamide-[2,4,5,6,- $\left.\mathrm{d}_{4}\right], 25 \mathrm{mM}$ calcium pantothenate$\left[{ }^{13} \mathrm{C}_{3},{ }^{15} \mathrm{~N}\right], 25 \mathrm{mM}$ biotin- $\left[\mathrm{d}_{2}\right], 3.4 \mathrm{mM}$ retinol- $\left[\mathrm{d}_{5}\right], 5 \mathrm{mM}$ $\alpha$-tocopherol-[ring-5,7-dimethyl- $\mathrm{d}_{6}$ ], and $2.5 \mathrm{mM}$ vitamin $\mathrm{K}$ $\left[5,6,7,8-\mathrm{d}_{4}, 2-\right.$ methyl- $\left._{3}\right]$ in $\mathrm{MeOH}$ and $0.28 \mathrm{mM}$ vitamin $\mathrm{D}_{3^{-}}$ $\left[6,19,19-d_{3}\right]$ in ethanol and stored in liquid nitrogen $\left(-196^{\circ} \mathrm{C}\right)$.

Mixtures containing all water-soluble vitamins in $\mathrm{H}_{2} \mathrm{O}$ and all fat-soluble vitamins in $\mathrm{MeOH}$ were prepared with concentrations at $200 \mu \mathrm{M}$, and mixtures of IS with concentrations at $100 \mu \mathrm{M}$ for water-soluble vitamins in $\mathrm{D}_{2} \mathrm{O}$ and for fat-soluble vitamins in $\mathrm{MeOH}$ were prepared periodically and stored at $-20^{\circ} \mathrm{C}$. About $1.5 \mathrm{~g} / \mathrm{L}$ solution of $\mathrm{BHT}$ in $\mathrm{MeOH}$ was also prepared and stored at $-20^{\circ} \mathrm{C}$. Finally, six calibration levels were prepared by diluting mixture solutions of water-soluble and fat-soluble vitamins in $\mathrm{MeOH}$ to give final concentrations in the range of $0.3-10 \mu \mathrm{M}$ for all analytes. About $4 \mu \mathrm{M}$ watersoluble and fat-soluble vitamin IS and $0.75 \mathrm{~g} / \mathrm{L} \mathrm{BHT}$ (for vitamins stabilizations) were also added. All solutions were protected from UV light during preparation, use, and storage.

\section{Blood and tear preparation}

Blood and tear samples were obtained from individuals with informed, documented consent by a phlebotomist in a local clinic following IRB protocols (M0934, [336669-5]), approved by Michigan Tech and UP Portage Health review boards. In total, $70 \mu \mathrm{L}$ tears were collected from each individual by placement of two Schirmer strips (each marked to $35 \mu \mathrm{L}$ ), one inside each of the patient's lower eyelids. Strips were stored in a $1.5 \mathrm{~mL}$ eppendorf tube at $-20^{\circ} \mathrm{C}$. Blood samples were collected in no-additive tubes (red top) and centrifuged for $10 \mathrm{~min}$ at 896 relative centrifugal force (rcf) to separate plasma. The plasma was removed and stored at $-20^{\circ} \mathrm{C}$ in a glass container.

For extraction of water-soluble and fat-soluble vitamins simultaneously from blood, $800 \mu \mathrm{L}$ of $\mathrm{MeOH} / \mathrm{ACN} /$ Acetone, $1: 1: 1(\mathrm{v} / \mathrm{v} / \mathrm{v})$, containing $1 \mu \mathrm{M}$ of each water-soluble and fatsoluble vitamin IS and $200 \mu \mathrm{L}$ of $1.5 \mathrm{~g} / \mathrm{L}$ BHT solution were added to $200 \mu \mathrm{L}$ plasma and vortexed. The mixture was incubated at $4^{\circ} \mathrm{C}$ for $10 \mathrm{~min}$ to precipitate proteins, then vortexed, and centrifuged for $10 \mathrm{~min}$ at $896 \mathrm{rcf}$. The supernatant (serum) was dried under nitrogen and analytes were reconstituted in $100 \mu \mathrm{L}$ of $0.1 \%$ FA in water/MeOH, 9:1 (v/v).

Simultaneous extraction of water-soluble and fat-soluble vitamins from tears was accomplished from the two tear strips (70 $\mu \mathrm{L}$ tears) via the addition of $400 \mu \mathrm{L} \mathrm{MeOH}, \mathrm{ACN}$, acetone (1:1:1 by volume). A $2 \mu \mathrm{M}$ water-soluble and fat-soluble IS was added along with $70 \mu \mathrm{L}$ BHT solution for vitamin stabilization. The vial containing sample and solvents was incubated at $4^{\circ} \mathrm{C}$ for $10 \mathrm{~min}$, then centrifuged at $896 \mathrm{rcf}$ for $10 \mathrm{~min}$. Supernatant was dried under a gentle stream of nitrogen and reconstituted in $100 \mu \mathrm{L}$ of $0.1 \% \mathrm{FA}$ in water/MeOH, 9:1 (v/v). 


\section{LC-MS/MS analysis}

LC-MS/MS was performed using an Accela LC quaternary pump coupled with an autosampler and an LCQ Fleet MS with an electrospray (ESI) probe (Thermo Scientific, Waltham, MA). Separation was performed using a Waters (Milford, MA) Atlantis T3 column, $2.1 \mathrm{~mm} \times 150 \mathrm{~mm}$, packed with $3 \mu \mathrm{m} \mathrm{C}_{18}$ silica and $100 \dot{\mathrm{A}}$ pore size coupled with a guard column (Atlantis T3 Sentry, $2.1 \mathrm{~mm} \times 10 \mathrm{~mm}$ ). A 1:5 ratio postcolumn binary fixed flow splitter (20\% to MS, $80 \%$ to waste) was used to increase the analyte ionization efficiency (this is unnecessary with a heated ESI probe.).

The ternary mobile phases were (a) $0.1 \% \mathrm{FA}$ in water, (b) $0.1 \% \mathrm{FA}$ in $\mathrm{ACN}$, and (c) $5 \mathrm{mM}$ ammonium formate in $\mathrm{MeOH}$. The gradient was $0 \mathrm{~min}, 100 \% \mathrm{~A} ; 7 \mathrm{~min}, 100 \% \mathrm{~A}$; $12 \mathrm{~min}, 50 \% \mathrm{~A} / 50 \% \mathrm{~B} ; 16 \mathrm{~min}, 20 \% \mathrm{~A} / 80 \% \mathrm{~B} ; 16.01 \mathrm{~min}$, $100 \%$ C; $34 \mathrm{~min}, 100 \%$ C. ESI and MS parameters were optimized over six segments with $4 \mathrm{kV}$ spray voltage and $275^{\circ} \mathrm{C}$ capillary temperature for all vitamins. The capillary and tube lens voltages were optimized over time and after instrument maintenance and were in the range of $1-46$ and $60-115 \mathrm{~V}$, respectively. The electrospray probe was operated in the positive ion mode in segments 1-6 and the sheath gas flow rate was set to 10 and 20 (arbitrary units), respectively for watersoluble and fat-soluble vitamins. A $25 \mu \mathrm{L}$ sample with full loop injection was introduced at a flow rate of $0.2 \mathrm{~mL} / \mathrm{min}$ for the first $16 \mathrm{~min}$ and $0.4 \mathrm{~mL} / \mathrm{min}$ for the last $18 \mathrm{~min}$. The column was re-equilibrated between runs with 20 column volumes of mobile phase A for $20 \mathrm{~min}$. Autosampler and column temperatures were fixed at 5 and $25^{\circ} \mathrm{C}$, respectively. Nitrogen was used as a nebulizing gas. All data acquisition was done with Xcalibur 2.3 (version C; Thermo Fisher Scientific, Waltham, MA).

\section{Linearity and limit of detection}

For vitamin quantifications, signals from triplicate analysis of the six calibration solutions were measured and calibration curves were built by plotting the ratio of analyte peak area to the area of IS vs. concentration using the least-squares regression method.

Limits of detection (LOD) and limits of quantification (LOQ) were determined based on the standard deviation method. ${ }^{38}$ The LOD and LOQ were respectively defined as 3 and 10 times the $S / m$ ratio, where $S$ is the signal standard deviation from the replicate injections $(n=7)$ of a low-level sample (standard solution, tear, or blood serum) and $m$ is the slope of the linear calibration curve. The standard deviations were calculated for concentrations lower than the LOQ and the RSD were $<20 \%$.

\section{Results and Discussion}

In our related publication, ${ }^{6}$ we developed separate HPLC methods for the determination of water-soluble and fat-soluble vitamins in tears and blood serum. These methods required $18 \mathrm{~min}$ for the water-soluble vitamins separation and $25 \mathrm{~min}$ for the fat-soluble vitamins separation and each method needed $28 \mathrm{~min}$ for column re-equilibrium. Furthermore, separate extractions were required and the total blood serum volume was $500 \mu \mathrm{L}$. We used these methods as a starting point for development of a combined method, which is described here. Original implementations of the combined method took $>60 \mathrm{~min}$, but flow rate and gradient optimization enabled run times to be cut in half. The combined method described herein can detect 12 water-soluble and fat-soluble vitamins in $<34$ min using three mobile phases which reduced the total sample preparation and analysis time by $42 \%$ compared to our separate methods. ${ }^{6}$ Eight of these vitamins were successfully extracted and detected from tears and blood serum using a single extraction step in $<30 \mathrm{~min}$ with a total sample volume of $200 \mu \mathrm{L}$ blood serum and $70 \mu \mathrm{L}$ tears. This method therefore enables detection of a majority of water-soluble and fatsoluble vitamins simultaneously from limited sample volumes.

\section{Optimization of LC-MS/MS conditions}

Using the ternary gradient elution and ESI-MS/MS conditions described in "LC-MS/MS Analysis" section, water-soluble and fat-soluble vitamins eluted from the LC column in $<34 \mathrm{~min}$ as shown in Figure 1. The chromatography run was divided into six segments with respect to the analyte retention times to allow the ion trap mass analyzer to scan the precursor ions (listed in Table 1) using selected ion scanning mode. For quantifications, MS/MS specifications were used with selected reaction monitoring. Thus, specific fragment ions of each precursor ion were captured in order to increase the resolution and selectivity.

Figure 1 shows the chromatograms achieved by a standard mixture solution containing the 12 water-soluble and fatsoluble vitamins under described LC-ESI-MS/MS conditions. Chromatograms were generated from the signals for the MS/MS fragment ions listed in Table 1. Peak areas were used for quantification.

The separation mechanism selected for detection of watersoluble and fat-soluble vitamins was based on the structure of the compounds. An extensive literature review was conducted to minimize the time and cost for the method development. Water-soluble vitamins are polar compounds while fat-soluble vitamins are relatively less polar than water-soluble vitamins. Thus, a reversed phase $\mathrm{C}_{18}$ column was selected because it is known to be an appropriate method for separation of compounds that differ by polarity. Reverse phase separations start with a high aqueous mobile phase then increase the solvent composition throughout the gradient. Acetonitrile and methanol are common solvents used in reversed phase separations. The LC separation was optimized by changing compositions of the mobile phases in order to achieve the best and fastest separation (Supporting Information Figure S1). For the mass spectrometry detection, the polar functional groups in water-soluble vitamin structures enable easy ionization by protonation. Ion formation was enhanced by $0.1 \%$ FA added to the mobile phases A and B (mass spectra are shown in Figure 2). Fat-soluble vitamins are considerably less polar than water-soluble vitamins and lack functional groups that readily accept or donate electrons, so mobile phase additives were necessary to facilitate their ionization with adduct formation using the hydroxyl (vitamin $\mathrm{A}, \mathrm{D}_{3}$, $25[\mathrm{OH}] \mathrm{D}_{3}$, and $\mathrm{E}$ ) or oxygen (vitamin $\mathrm{K}_{1}$ ) groups in their structures. Mobile phase additives that have been used to promote ion formation for fat-soluble vitamins include formic acid, ${ }^{7}$ silver perchlorate, ${ }^{39}$ ammonium acetate, ${ }^{40}$ ammonium formate ${ }^{41}$, or cesium acetate. ${ }^{42}$ We systematically tested these additives at different concentrations. Cationic adducts from ammonium acetate, silver perchlorate, and cesium acetate did not yield sufficient spectral intensity (Figure 3). However, the hydrogen adduct peak height generated by $5 \mathrm{mM}$ ammonium formate demonstrated sufficiently enhanced ionization concurrent with increasing mobile phase $\mathrm{C} \mathrm{pH}$ to $\sim 6$ (below $\mathrm{pKa}$ of 9.25 for ammonium ion) and was thus chosen as the third mobile phase modifier that elutes fat-soluble vitamins. The mass spectra for 


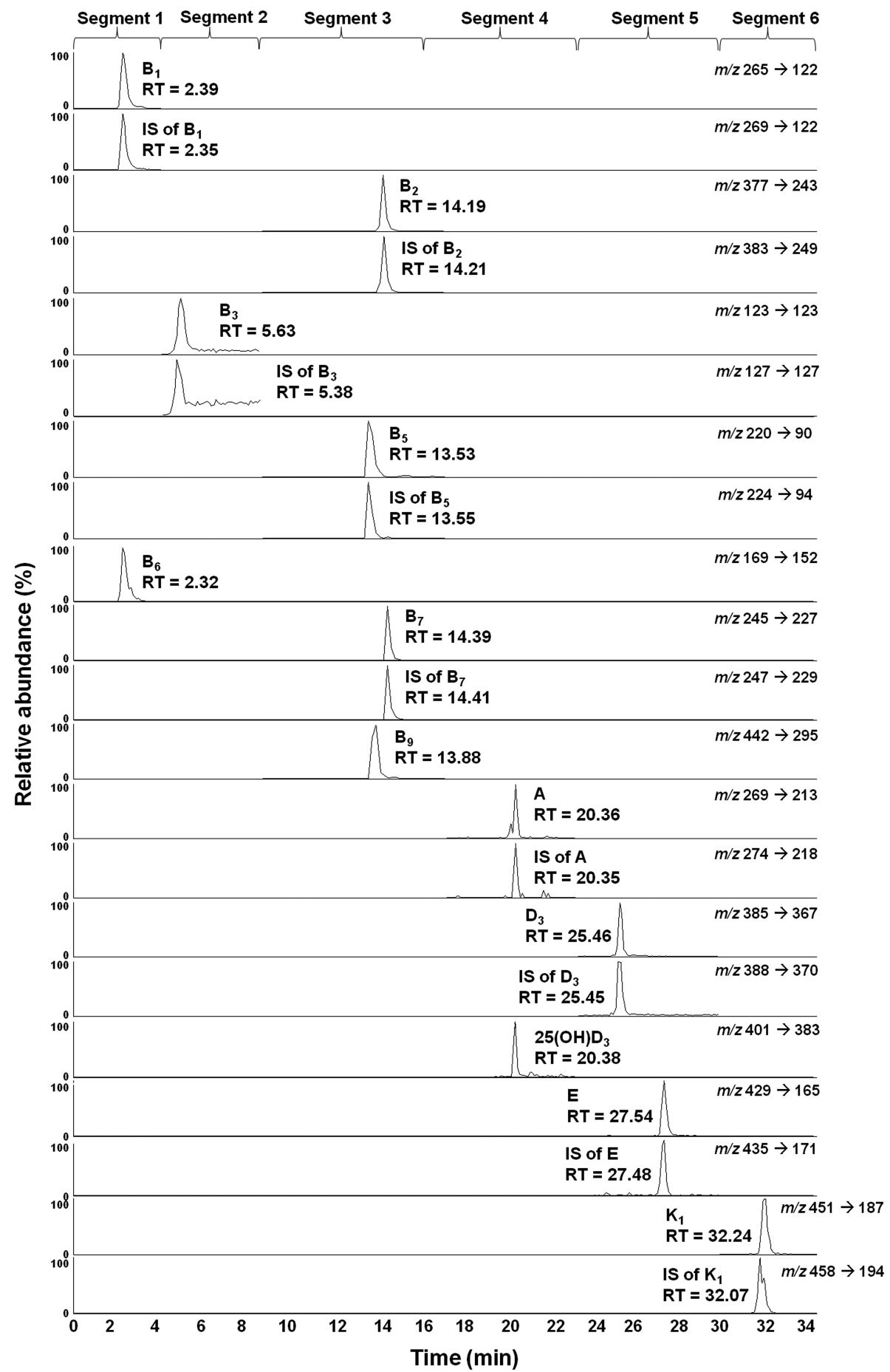

Figure 1. Chromatograms of 12 water-soluble and fat-soluble vitamins detected simultaneously with the LC-ESI-MS/ MS method using a standard vitamin solution.

Total analysis time was $34 \mathrm{~min}$. Peaks illustrate the selected fragment ions of the precursor ions generated under selected reaction monitoring mode and include the analyte names and retention times (RT). For quantification of vitamins $B_{6}$ and $B_{9}$, the peak area of vitamin $B_{2}$ internal standard (IS) was used; and for quantification of $25(\mathrm{OH}) \mathrm{D}_{3}$, the peak area of the vitamin $\mathrm{D}_{3}$ IS was used.

all 12 vitamins and IS are shown in Figure 2 with the base peaks representing the protonated vitamins (Table 1).

\section{Analysis of standard vitamins with optimized LC-MS}

Using the identified LC-MS parameters, the water-soluble and fat-soluble vitamin retention times were determined from three replicate injections of the $0.3-10 \mu \mathrm{M}$ concentrations as documented in Table 1. A summary of the chromatography and mass spectrometry parameters for detection of water- soluble and fat-soluble vitamins simultaneously is provided in Table 1. All 12 vitamins were detected in positive ESI mode. Vitamin $\mathrm{B}_{1}$ and its corresponding IS (thiamine- $\left[{ }^{13} \mathrm{C}_{4}\right]$ ) precursor ions were observed as molecular ions, $[\mathrm{M}]^{+}$. The precursor ions of vitamin $A$ and its IS (retinol- $\left[\mathrm{d}_{5}\right]$ ) resulted from the dehydration of the protonated molecule, $\left[\mathrm{M}+\mathrm{H}-\mathrm{H}_{2} \mathrm{O}\right]^{+}$. Peaks at $\mathrm{m} / \mathrm{z} 429$ and 435 were observed for vitamin $\mathrm{E}$ and its IS (tocopherol- $\left[\mathrm{d}_{6}\right]$ ), which are produced from dehydrogenation of the protonated molecule to yield $\left[\mathrm{M}+\mathrm{H}-\mathrm{H}_{2}\right]^{+43,44}$. For all 
Table 1. Chromatography and Mass Spectrometry Results for Simultaneous Detection of Water-Soluble and Fat-Soluble Vitamins

\begin{tabular}{|c|c|c|c|c|c|c|c|}
\hline $\begin{array}{l}\text { Time } \\
\text { period } \\
(\min )\end{array}$ & Vitamins & $\begin{array}{l}\text { Molecular } \\
\text { weight } \\
\text { (Da) }\end{array}$ & $\begin{array}{l}\text { Precursor } \\
\text { ion } \\
(m / z)\end{array}$ & $\begin{array}{c}\text { Collision } \\
\text { energy } \\
(\mathrm{eV})\end{array}$ & $\begin{array}{l}\text { Fragment ion for } \\
\text { quantification } \\
(\mathrm{m} / \mathrm{z})\end{array}$ & $\begin{array}{l}\text { Retention } \\
\text { time } \\
(\mathrm{min})\end{array}$ & $\begin{array}{c}\text { Other fragment } \\
\text { ions } \\
(\mathrm{m} / \mathrm{z})\end{array}$ \\
\hline \multirow[t]{3}{*}{$0-4$} & $\mathrm{~B}_{1}$, thiamine & 300 & $265.0[\mathrm{M}]^{+}$ & 20 & 122 & $2.36 \pm 0.03$ & 144,156 \\
\hline & Thiamine- $\left[{ }^{13} \mathrm{C}_{4}\right]$ & 304 & $269.0\left[^{[M]^{+}}\right.$ & 20 & 122 & $2.35 \pm 0.00$ & $251,160,148$ \\
\hline & $\mathrm{B}_{6}$, pyridoxamine & 168 & $169.1[\mathrm{M}+\mathrm{H}]^{+}$ & 18 & $152\left[\mathrm{M}+\mathrm{H}-\mathrm{H}_{2} \mathrm{O}\right]^{+}$ & $2.31 \pm 0.02$ & - \\
\hline \multirow[t]{2}{*}{$4-8.5$} & $\mathrm{~B}_{3}$, nicotinamide & 122 & $123.2[\mathrm{M}+\mathrm{H}]^{+}$ & 0 & 123 & $5.48 \pm 0.15$ & 105,80 \\
\hline & Nicotinamide- $\left[\mathrm{d}_{4}\right]$ & 126 & $127.2[\mathrm{M}+\mathrm{H}]^{+}$ & 0 & 127 & $5.38 \pm 0.04$ & 109,83 \\
\hline \multirow[t]{7}{*}{$8.5-16$} & $\mathrm{~B}_{2}$, riboflavin & 376 & $377.1[\mathrm{M}+\mathrm{H}]^{+}$ & 23 & 243 & $14.19 \pm 0.00$ & 359 \\
\hline & Riboflavin- $\left[{ }^{13} \mathrm{C}_{4},{ }^{15} \mathrm{~N}_{2}\right]$ & 382 & $383.2[\mathrm{M}+\mathrm{H}]^{+}$ & 23 & 249 & $14.21 \pm 0.00$ & 365 \\
\hline & $\mathrm{B}_{5}$, pantothenic acid & 219 & $220.0[\mathrm{M}+\mathrm{H}]^{+}$ & 18 & 90 & $13.60 \pm 0.08$ & 202,184 \\
\hline & Pantothenate- $\left[{ }^{13} \mathrm{C}_{3},{ }^{15} \mathrm{~N}\right]$ & 223 & $224.2[\mathrm{M}+\mathrm{H}]+$ & 18 & 94 & $13.57 \pm 0.06$ & 205,188 \\
\hline & $\mathrm{B}_{7}$, biotin & 244 & $245.0[\mathrm{M}+\mathrm{H}]^{+}$ & 16 & $227\left[\mathrm{M}+\mathrm{H}-\mathrm{H}_{2} \mathrm{O}\right]^{+}$ & $14.44 \pm 0.07$ & - \\
\hline & Biotin- $\left[\mathrm{d}_{2}\right]$ & 246 & $247.1[\mathrm{M}+\mathrm{H}]^{+}$ & 16 & $229\left[\mathrm{M}+\mathrm{H}-\mathrm{H}_{2} \mathrm{O}\right]^{+}$ & $14.43 \pm 0.06$ & - \\
\hline & $\mathrm{B}_{9}$, folic acid & 441 & $442.0[\mathrm{M}+\mathrm{H}]^{+}$ & 19 & 295 & $13.88 \pm 0.00$ & 424,313 \\
\hline \multirow[t]{3}{*}{$16-23$} & A, retinol & 286 & $269.3\left[\mathrm{M}+\mathrm{H}-\mathrm{H}_{2} \mathrm{O}\right]^{+}$ & 25 & 213 & $20.36 \pm 0.00$ & $157,119,93$ \\
\hline & Retinol- $\left[\mathrm{d}_{5}\right]$ & 291 & $274.2\left[\mathrm{M}+\mathrm{H}-\mathrm{H}_{2} \mathrm{O}\right]^{+}$ & 25 & 218 & $20.35 \pm 0.00$ & $162,124,93$ \\
\hline & $25(\mathrm{OH})-\mathrm{D}_{3}$ & 400 & $401.1[\mathrm{M}+\mathrm{H}]^{+}$ & 16 & $383\left[\mathrm{M}+\mathrm{H}-\mathrm{H}_{2} \mathrm{O}\right]^{+}$ & $20.36 \pm 0.03$ & 365 \\
\hline \multirow[t]{4}{*}{$23-29.5$} & $\mathrm{D}_{3}$, cholecalciferol & 384 & $385.4[\mathrm{M}+\mathrm{H}]^{+}$ & 22 & $367\left[\mathrm{M}+\mathrm{H}-\mathrm{H}_{2} \mathrm{O}\right]^{+}$ & $25.44 \pm 0.04$ & 259 \\
\hline & Cholecalciferol- $\left[\mathrm{d}_{3}\right]$ & 387 & $388.3[\mathrm{M}+\mathrm{H}]^{+}$ & 22 & $370\left[\mathrm{M}+\mathrm{H}-\mathrm{H}_{2} \mathrm{O}\right]^{+}$ & $25.41 \pm 0.09$ & 259 \\
\hline & E, $\alpha$-tocopherol & 430 & $429.4\left[\mathrm{M}+\mathrm{H}-\mathrm{H}_{2}\right]^{+}$ & 27 & 165 & $27.50 \pm 0.10$ & 205 \\
\hline & Tocopherol- $\left[\mathrm{d}_{6}\right]$ & 436 & $435.6\left[\mathrm{M}+\mathrm{H}-\mathrm{H}_{2}\right]^{+}$ & 27 & 171 & $27.48 \pm 0.06$ & 417,211 \\
\hline \multirow[t]{2}{*}{$29.5-34$} & $\mathrm{~K}_{1}$, phylloquinone & 450 & $451.6[\mathrm{M}+\mathrm{H}]^{+}$ & 25 & 187 & $32.17 \pm 0.07$ & 433,225 \\
\hline & Phylloquinone- $\left[\mathrm{d}_{7}\right]$ & 457 & $458.4[\mathrm{M}+\mathrm{H}]^{+}$ & 25 & 194 & $31.98 \pm 0.08$ & 440,232 \\
\hline
\end{tabular}

other vitamins and their IS, precursor ions were generated from the protonated molecule, $[\mathrm{M}+\mathrm{H}]^{+}$. The time periods of the six segments are also shown in Table 1 . For quality assurance, Table 1 also lists some fragment ions produced with the optimized collision energies along with ones used for quantification.

\section{Linearity, $L O D, L O Q$, and precision}

The LOD and LOQ were calculated by the method described in the "Linearity and limit of detection" section and were determined in standard solutions for all 12 vitamins, and in tears and serum samples for detectable vitamins. Table 2 reports the standard curves and $R^{2}$ values for each of the 12 vitamins. The instrument response was linear for all vitamins with correlation coefficients $>0.99$. The ranges of linearity for vitamins $B_{5}$ and $\mathrm{B}_{6}$ were up to $200 \mu \mathrm{M}, \mathrm{B}_{2}, \mathrm{~B}_{3}, \mathrm{~B}_{9}, 25(\mathrm{OH}) \mathrm{D}_{3}, \mathrm{D}_{3}, \mathrm{E}$, and $\mathrm{K}_{1}$ were up to $100 \mu \mathrm{M}, \mathrm{B}_{1}$, and $\mathrm{A}$ were up to $50 \mu \mathrm{M}$ and $\mathrm{B}_{7}$ up to $10 \mu \mathrm{M}$. These values indicate sufficiently high reliability that is consistent with other published techniques. ${ }^{13}$

Inter-day $(n=7)$ and intra-day $(n=6)$ precision were evaluated with replicate injections of samples. RSD values were in the range of 1.6-12\% except for tear vitamin $\mathrm{B}_{9}$ (Table 3). Tear $\mathrm{B}_{9}$ precision was low (29\% and 57\% RSD) and as such, calculated $\mathrm{B}_{9}$ concentrations in tears may not be reliable. Recoveries of vitamins were estimated by spiking the tear and serum samples and calculating the extracted amounts, which were 84.8-102\% for all detectable vitamins except for serum $\mathrm{B}_{9}$. Serum $B_{9}$ recovery was as low as $36.1 \%$, which caused the calculated amounts in serum samples to be less reliable than other vitamins. Precisions, except for vitamin $\mathrm{B}_{9}$ were sufficient for use in subsequent assays and consistent with other vitamin techniques. ${ }^{13,22} \mathrm{~B}_{9}$ recovery was also tested using a stable $\mathrm{B}_{9}$ isotope, $B_{9}-\left[{ }^{13} \mathrm{C}_{5}\right]$, as an internal standard. Low recoveries of $\sim 10 \%$ were still obtained from the serum. This result is likely due to the combination of instability and low concentrations for this tested form of vitamin $\mathrm{B}_{9}$ in serum samples. According to the Mayo Clinic, ${ }^{45}$ more sensitive methods such as competitive binding assays are required for reliable detection of vitamin $\mathrm{B}_{9}$. In these assays, folate is measured as an indicator of all folic acid derivatives, which in serum is almost entirely present as $\mathrm{N}-(5)$-methyl tetrahydrofolate. ${ }^{46}$

\section{Tears and serum analysis}

To test the combined method performance on complex biological samples, vitamins were extracted from tears and blood serum of five human subjects under procedures described in the "Blood and tear preparation" section, and analyzed with the LCMS/MS combined detection method for water-soluble and fatsoluble vitamins. Vitamin concentrations resulting from the five individuals are summarized in Table 4. The combined method detected vitamins $\mathrm{B}_{1}, \mathrm{~B}_{2}, \mathrm{~B}_{3}, \mathrm{~B}_{5}, \mathrm{~B}_{6}, \mathrm{~B}_{9}, \mathrm{~A}$, and $\mathrm{E}$ in blood serum and vitamins $\mathrm{B}_{1}, \mathrm{~B}_{2}, \mathrm{~B}_{3}, \mathrm{~B}_{5}, \mathrm{~B}_{6}, \mathrm{~B}_{9}$, and $\mathrm{E}$ in tears. Serum $\mathrm{B}_{9}$ recovery and tear $\mathrm{B}_{9}$ precision were low as described in the "Linearity, LOD, LOQ, and precision" section, thus the detected amounts are not reported in Table 4. This method was also tested on newborn tears resulting in detection of vitamin $\mathrm{K}_{1}$. The detectable vitamin $\mathrm{K}_{1}$ concentrations in newborns can be explained by the vitamin $\mathrm{K}$ shot that they receive after birth. This data will be reported in a future article. Figure 4 shows the vitamin chromatograms achieved from analysis of a tear sample (Figure 4a) and a serum sample (Figure 4b) under the described combined method. Our combined method, compared to our previously published method, is capable of detecting most watersoluble and fat-soluble vitamins simultaneously in human blood and it is also the first demonstration of simultaneous detection of these two groups of vitamins in human tears. A longitudinal study will be published with the application of this combined method for vitamin detections in infants and parents.

Our combined method was also tested using a triple quadrupole MS with higher sensitivity at our co-author's laboratory in the Kellogg Eye Institute and the same vitamins remained undetectable. Undetected $\mathrm{K}_{1}$ in serum was attributed to the very low sample concentrations (0.0004-0.002 $\left.\mu \mathrm{M}^{47}\right)$ which were lower than our method LOD. $\mathrm{K}_{1}$ was also undetectable in serum of newborns which lead us to hypothesize that vitamin $\mathrm{K}$ is probably higher in tears than serum of newborns. The undetected $\mathrm{B}_{7}$ and vitamin D metabolites were tested for potential matrix effects. Standard solutions of these vitamins were spiked into pooled serum and tear samples such that precision and 


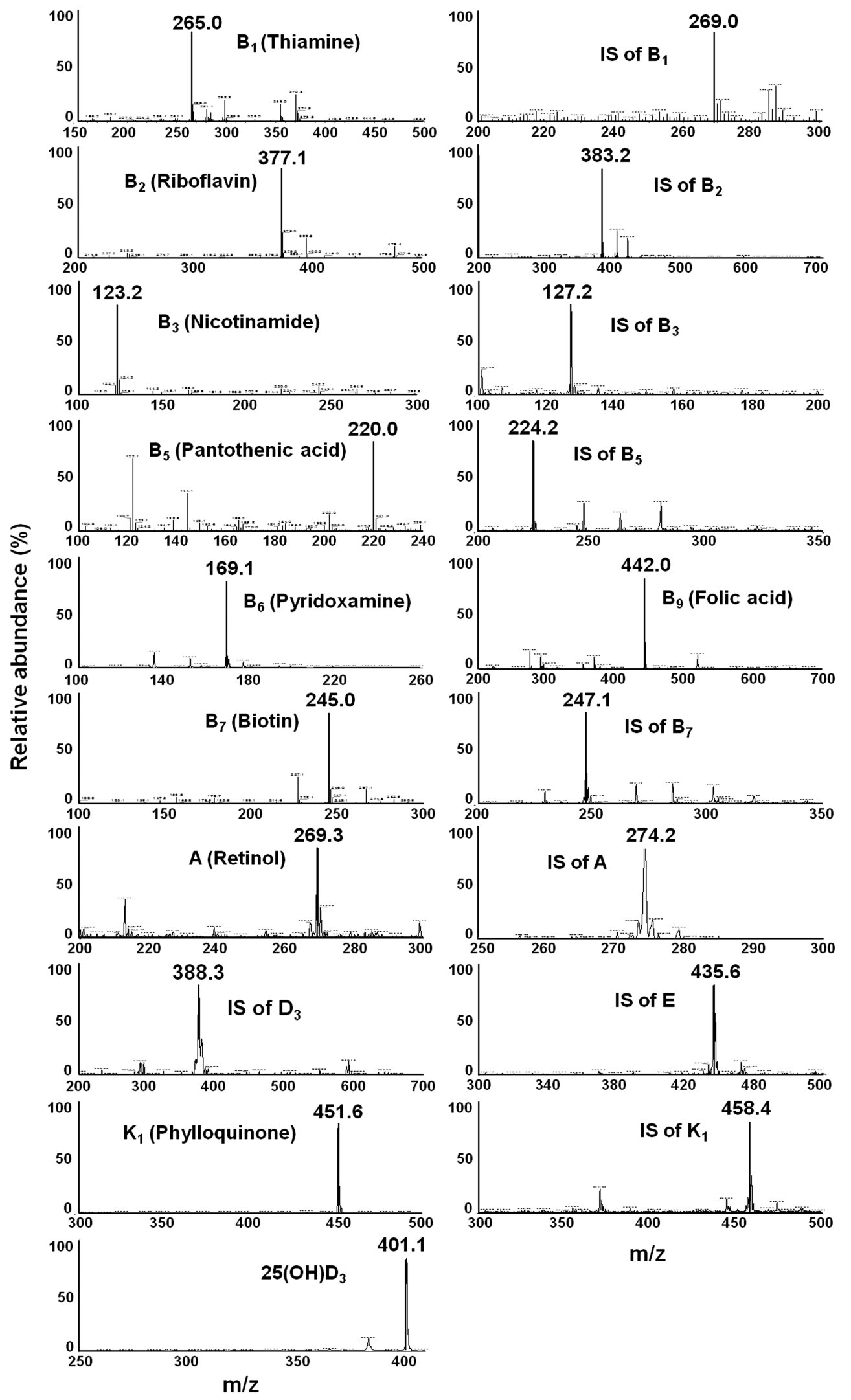

Figure 2. ESI-mass spectra for water-soluble vitamins (with $0.1 \%$ formic acid in mobile $A$ and $B$ ) and fat-soluble vitamins (with $5 \mathrm{mM}$ ammonium formate in mobile phase C) and their corresponding internal standards (stable isotope substituted analytes) generated from a vitamin standard solution.

Precursor ions of the analytes are labeled on the spectra. The fragment ions for each of these precursor ions are reported in Table 1 and were used for quantification. The mass spectra of vitamin $D_{3}$ and $E$ are shown in Figure 3. 

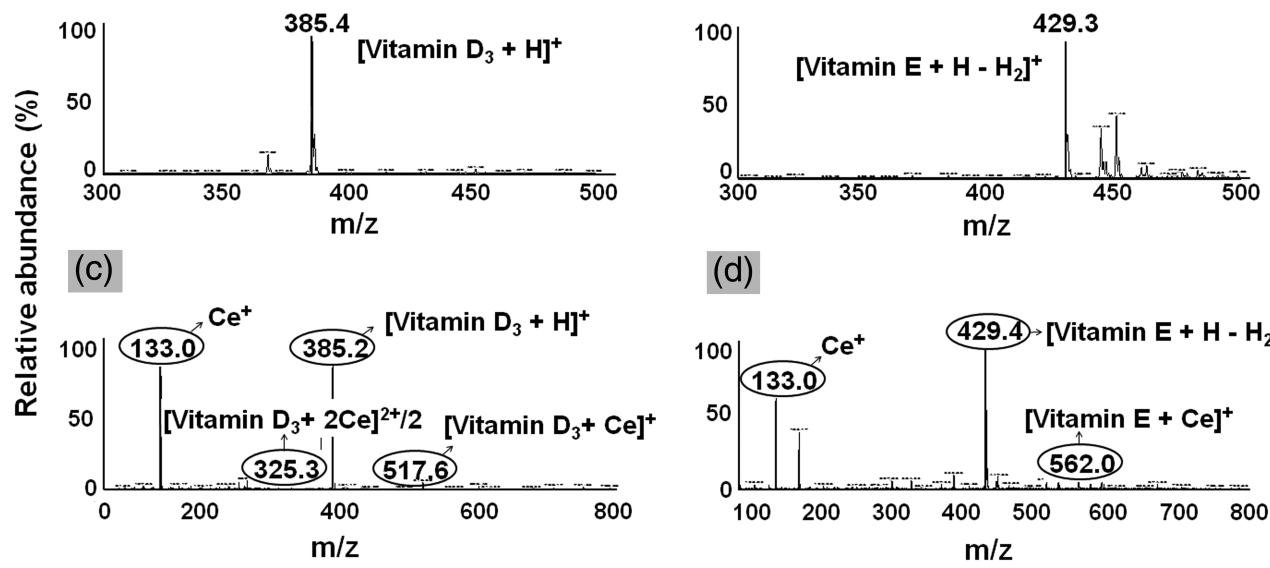

(d)

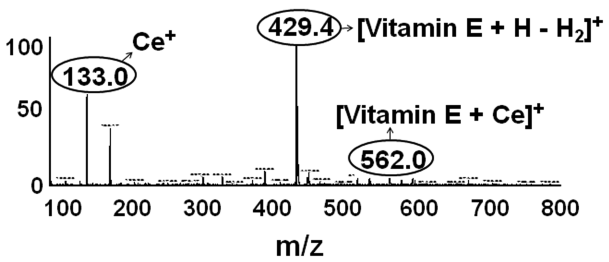

Figure 3. Mass spectra of (a) vitamin $D_{3}$ and (b) vitamin $E$ with ammonium formate compared to (c) vitamin $D_{3}$ and (d) vitamin $\mathrm{E}$ with cesium acetate.

Cesium cation $\left(\mathrm{Ce}^{+}\right)$adducts were not sufficiently intense for reliable detection, while the hydrogen adduct peak height generated by ammonium formate demonstrated sufficiently enhanced ionization and was chosen as the preferred mobile phase $\mathbf{C}$ modifier.

Table 2. Calibration Data, Limits of Detection (LOD), and Limits of Quantification (LOQ)

\begin{tabular}{|c|c|c|c|c|c|c|c|c|c|}
\hline Vitamins & $\begin{array}{c}\text { Calibration } \\
\text { curves }\end{array}$ & $\begin{array}{c}R^{2} \\
\text { correlation }\end{array}$ & $\begin{array}{c}\text { LOD (ng) in } \\
\text { standard solution }\end{array}$ & $\begin{array}{c}\text { LOQ (ng) in } \\
\text { standard solution }\end{array}$ & $\begin{array}{l}\text { LOD (ng) } \\
\text { in serum }\end{array}$ & $\begin{array}{l}\text { LOQ }(\mathrm{ng}) \\
\text { in serum }\end{array}$ & $\begin{array}{l}\text { LOD }(n g) \\
\text { in tear }\end{array}$ & $\begin{array}{l}\text { LOQ }(\mathrm{ng}) \\
\text { in tear }\end{array}$ & $\begin{array}{c}\text { Linear } \\
\text { range }(\mu \mathrm{M})\end{array}$ \\
\hline $\mathrm{B}_{1}$, thiamine & $y=0.3600 x+0.002$ & 0.9985 & 0.043 & 0.14 & 0.094 & 0.31 & 0.088 & 0.29 & $0.01-50$ \\
\hline $\mathrm{B}_{2}$, riboflavin & $y=0.2280 x+0.001$ & 0.9993 & 0.055 & 0.18 & 0.087 & 0.29 & 0.066 & 0.22 & $0.009-100$ \\
\hline $\mathrm{B}_{3}$, nicotinamide & $y=0.2539 x+0.033$ & 0.998 & 0.60 & 2.0 & 0.37 & 1.2 & 0.24 & 0.79 & $0.1-100$ \\
\hline $\mathrm{B}_{5}$, pantothenic acid & $y=0.2135 x+0.000$ & 0.9974 & 0.60 & 2.0 & 0.45 & 1.5 & 0.36 & 1.2 & $0.08-200$ \\
\hline $\mathrm{B}_{6}$, pyridoxamine & $y=0.0335 x+0.001$ & 0.9984 & 0.082 & 0.27 & 0.16 & 0.54 & 0.32 & 1.1 & $0.04-200$ \\
\hline $\mathrm{B}_{7}$, biotin & $y=0.1242 x+0.001$ & 0.9988 & 0.30 & 1.0 & - & - & - & - & $0.05-10$ \\
\hline $\mathrm{B}_{9}$, folic acid & $y=0.0221 x+0.000$ & 0.9963 & 0.60 & 2.0 & 0.64 & 2.1 & 5.3 & 18 & $0.06-100$ \\
\hline A, retinol & $y=0.7444 x+0.186$ & 0.9992 & 2.1 & 7.0 & 1.3 & 4.4 & - & - & $0.2-50$ \\
\hline $\mathrm{D}_{3}$, cholecalciferol & $y=0.2915 x+0.005$ & 0.9976 & 0.45 & 1.5 & - & - & - & - & $0.5-100$ \\
\hline $25(\mathrm{OH})-\mathrm{D}_{3}$ & $y=0.1029 x+0.002$ & 0.9987 & 2.5 & 8.2 & - & - & - & - & $0.2-100$ \\
\hline E, $\alpha$-tocopherol & $y=0.2658 x+0.031$ & 0.9954 & 1.4 & 4.6 & 1.1 & 3.6 & 0.28 & 0.92 & $0.1-100$ \\
\hline $\mathrm{K}_{1}$, phylloquinone & $y=0.0546 x+0.001$ & 0.998 & 0.74 & 2.5 & - & - & 0.12 & 0.41 & $0.07-100$ \\
\hline
\end{tabular}

recoveries were calculated. $\mathrm{B}_{7}$ and $\mathrm{D}$ vitamins recovery was 91.6-103\% with inter- and intra-day precision of $3.4-9.0 \%$. Thus, the undetected vitamins were not due to matrix effects. This is not surprising since the presence of IS would elucidate matrix effects. However, $\mathrm{B}_{7}$ and vitamin $\mathrm{D}$ are both proteinbound vitamins, ${ }^{48,49}$ such that a proteolysis step is required to break the protein bond and release the vitamins prior to protein precipitation. The body requires extremely small concentrations of $\mathrm{B}_{7}$ which can efficiently be recycled, and food sources with $\mathrm{B}_{7}$ are abundant, ${ }^{50}$ thus the inability to detect $\mathrm{B}_{7}$ is not a major concern. Deficiency of vitamin $\mathrm{K}$ is also quite rare because intestinal bacteria produce this vitamin, which is also abundant in many foods. ${ }^{51}$ The biologically active form of vitamin D is the $25(\mathrm{OH}) \mathrm{D}$ considered for nutritional health diagnosis. ${ }^{52}$ Thus, only one of the critical vitamins for nutritional health, $25(\mathrm{OH}) \mathrm{D}$, was undetectable in the time and resource-efficient combined method presented herein.

Comparisons of results with the literature revealed additional efficiencies with our combined method. Liquid-liquid extractions (LLE) with hazardous organic solvents (e.g., hexane) or solid-

Table 3. Recovery (\%), Intra-day, and Inter-day Precision (RSD)

\begin{tabular}{|c|c|c|c|c|c|c|c|c|}
\hline Vitamins & $\begin{array}{c}\text { Intra-day } \\
\text { precision in } \\
\text { standard solution }\end{array}$ & $\begin{array}{c}\text { Inter-day } \\
\text { precision in } \\
\text { standard solution }\end{array}$ & $\begin{array}{l}\text { Intra-day } \\
\text { precision in } \\
\text { serum }\end{array}$ & $\begin{array}{l}\text { Inter-day } \\
\text { precision in } \\
\text { serum }\end{array}$ & $\begin{array}{c}\text { Intra-day } \\
\text { precision in tear }\end{array}$ & $\begin{array}{c}\text { Inter-day } \\
\text { precision in tear }\end{array}$ & $\begin{array}{l}\text { Recovery } \\
\text { in serum }\end{array}$ & $\begin{array}{c}\text { Recovery } \\
\text { in tear }\end{array}$ \\
\hline $\mathrm{B}_{1}$, thiamine & 2.2 & 4.2 & 1.6 & 2.4 & 6.7 & 5.9 & 94.6 & 102 \\
\hline $\mathrm{B}_{2}$, riboflavin & 3.2 & 4.4 & 4.1 & 2.4 & 6.0 & 7.4 & 100.7 & 98.4 \\
\hline $\mathrm{B}_{3}$, nicotinamide & 3.4 & 7.2 & 2.2 & 3.9 & 7.2 & 7.6 & 98.5 & 91.4 \\
\hline $\mathrm{B}_{5}$, pantothenic acid & 3.6 & 9.8 & 4.7 & 4.3 & 3.8 & 7.6 & 87.9 & 86.8 \\
\hline $\mathrm{B}_{6}$, pyridoxamine & 3.0 & 4.8 & 4.7 & 6.4 & 8.5 & 8.1 & 93.7 & 92 \\
\hline $\mathrm{B}_{7}$, biotin & 4.4 & 6.8 & - & - & - & - & - & - \\
\hline $\mathrm{B}_{9}$, folic acid & 11 & 10 & 7.1 & 8.7 & 29 & 57 & 36.1 & 84.8 \\
\hline A, retinol & 8.1 & 10 & 9.8 & 12 & - & - & 89 & - \\
\hline $\mathrm{D}_{3}$, cholecalciferol & 8.5 & 8.2 & - & - & - & - & - & - \\
\hline $25(\mathrm{OH})-\mathrm{D}_{3}$ & 7.5 & 8.4 & - & - & - & - & - & - \\
\hline E, $\alpha$-tocopherol & 3.2 & 4.9 & 4.6 & 2.5 & 6.0 & 7.7 & 94 & 91.7 \\
\hline $\mathrm{K}_{1}$, phylloquinone & 5.0 & 9.4 & - & - & 6.4 & 7.9 & - & 87.2 \\
\hline
\end{tabular}


Table 4. Vitamin Concentrations $(\mu \mathrm{M})$ in Tears and Blood Serum of Five Tested Individuals

\begin{tabular}{|c|c|c|c|c|c|c|c|c|c|c|}
\hline \multirow[b]{2}{*}{ Vitamins } & \multicolumn{2}{|c|}{ Sample 1} & \multicolumn{2}{|c|}{ Sample 2} & \multicolumn{2}{|c|}{ Sample 3} & \multicolumn{2}{|c|}{ Sample 4} & \multicolumn{2}{|c|}{ Sample 5} \\
\hline & Tear & Serum & Tear & Serum & Tear & Serum & Tear & Serum & Tear & Serum \\
\hline $\mathrm{B}_{1}$, thiamine & 0.022 & 0.054 & 0.038 & 0.14 & N.D. & 0.13 & 0.027 & 0.013 & N.D. & 0.053 \\
\hline $\mathrm{B}_{2}$, riboflavin & 0.018 & 0.034 & N.D. & 0.036 & 0.060 & 0.034 & 0.032 & N.D. & 0.015 & 0.018 \\
\hline $\mathrm{B}_{3}$, nicotinamide & 4.0 & 1.9 & 1.3 & 0.92 & 5.0 & 2.4 & 1.3 & 1.1 & 6.9 & 0.35 \\
\hline $\mathrm{B}_{5}$, pantothenic acid & 0.49 & 0.44 & 0.12 & 0.12 & 0.78 & 0.46 & 0.23 & 0.13 & 0.21 & 0.16 \\
\hline $\mathrm{B}_{6}$, pyridoxamine & N.D. & 0.62 & 0.083 & 0.71 & 0.12 & 1.3 & N.D. & 0.51 & 0.22 & 0.42 \\
\hline A, retinol & - & 1.1 & - & 2.9 & - & 2.7 & - & 1.4 & - & 1.0 \\
\hline E, $\alpha$-tocopherol & 0.13 & 14 & 0.090 & 16 & 0.42 & 20 & 0.055 & 9.2 & 0.12 & 7.1 \\
\hline
\end{tabular}

N.D., not detected.

phase extractions were primarily used to pre-concentrate vitamin analytes prior to HPLC. ${ }^{10,27,53}$ Our previously published separate water-soluble and fat-soluble vitamin methods ${ }^{5}$ included three LLE steps with hexane for fat-soluble vitamins. In the combined method herein, both groups of vitamins were extracted under a single extraction step using $\mathrm{MeOH} / \mathrm{ACN} /$ Acetone. Chatzimichalakis et al. ${ }^{10}$ published a simultaneous method for determination of only B-complexes (thiamine, riboflavin, nicotinic acid and nicotinamide, pyridoxine, folic acid, and cyanocobalamin) in blood serum and pharmaceuticals with solid-phase extraction and total analysis time of $27 \mathrm{~min}$. While in our combined method, six different $\mathrm{B}$ vitamins were extracted and eluted in $<15$ min with a flow rate of four times less and lower detection limits along with two fat-soluble vitamins.

In separate LC-MS methods, which are perceived to be the rapid standard, analysis takes $5 \mathrm{~min}$ with at least $15 \mathrm{~min}$ of active technician time for sample preparation for each vitamin. In the method published by Papadoyannis et al. ${ }^{53}$, solid-phase extraction cartridges were necessary to separate water-soluble and fat-soluble vitamins from $500 \mu \mathrm{L}$ of blood plasma. Further, vitamin detection required two different HPLC columns.
Our combined method analyzed eight vitamins in $<30 \mathrm{~min}$ with 3 min or less active technician time. Thus, our total assay time was $33 \mathrm{~min}$ for eight vitamins compared to $20 \mathrm{~min}$ per sample for a total time of $160 \mathrm{~min}$ for eight vitamins. Further, since our combined method requires only one column cleaning and stabilization cycle, while the separate assays require one each, solvent utilization decreases and instrument utilization time can increase by $42 \%$. Other sensitive quantification methods, such as enzyme linked immunosorbent assay (ELISA), require 2-24 $\mathrm{h}^{\prime}$ assay time and $\sim 30$ min active technician time per vitamin assay. When compared to the combined method presented herein, active technician time is reduced by a factor of $\sim 5$. Thus, the method presented herein demonstrates advantages beyond prior protocols for determination of water-soluble and fat-soluble vitamins in serum samples. To the best of our knowledge, simultaneous detection of water-soluble and fat-soluble vitamins in complex biological samples has not been previously reported in the literature. This combined method provides a resource-lean and efficient means to simultaneously detect most water-soluble and fat-soluble vitamins in complex biological samples. (a) Detected vitamins in tears

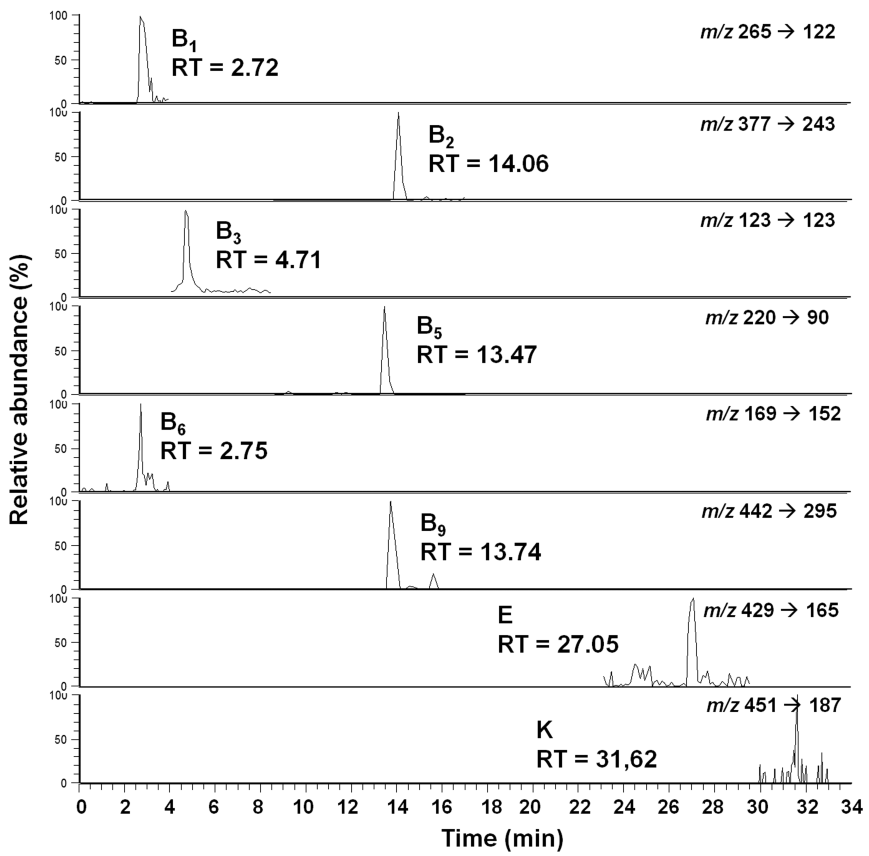

(b) Detected vitamins in blood serum

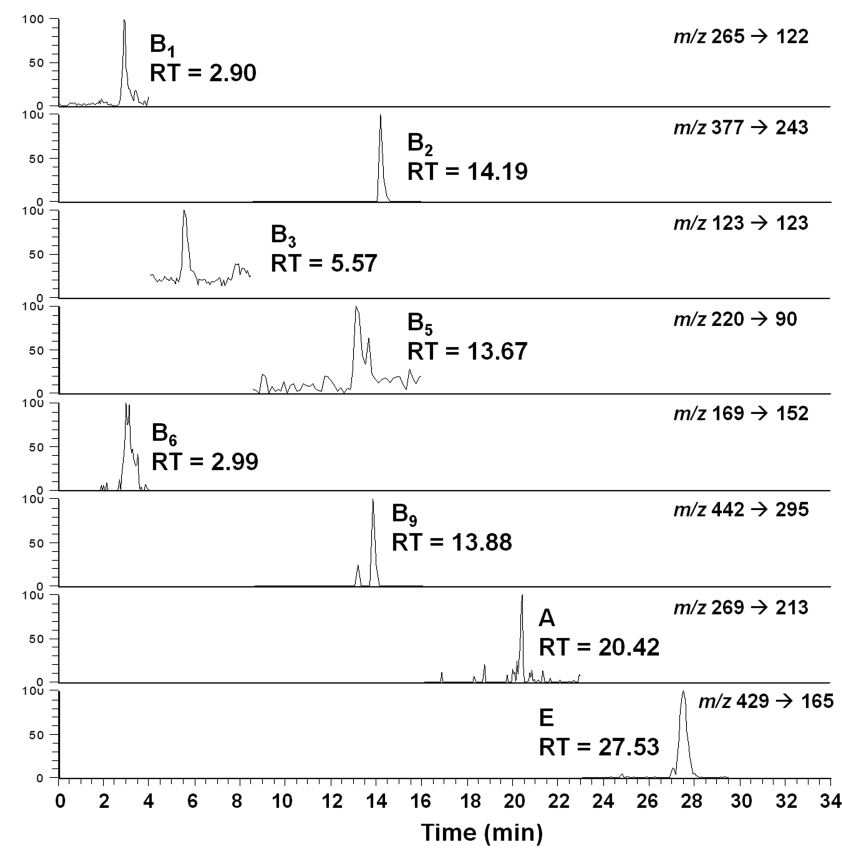

Figure 4. LC-MS/MS chromatograms of water-soluble and fat-soluble vitamins detected in (a) a tear sample and (b) a blood serum sample using the $<30 \mathrm{~min}$, reduced materials/chemicals combined vitamin method presented herein. 


\section{Conclusions}

This article describes the first demonstration of simultaneous determination and quantification of eight water-soluble and fat-soluble vitamins from clinically obtained human tears and blood serum samples. Our simultaneous protocol was able to capture 12 water-soluble and fat-soluble vitamins in $<34$ min from standard solutions, while among these vitamins, $\mathrm{B}_{1}, \mathrm{~B}_{2}, \mathrm{~B}_{3}$ (nicotinamide), $\mathrm{B}_{5}, \mathrm{~B}_{6}$ (pyridoxamine), $\mathrm{B}_{9}, \mathrm{E}$ ( $\alpha$-tocopherol), and $\mathrm{K}_{1}$ were simultaneously extracted and detected in tears and $\mathrm{B}_{1}, \mathrm{~B}_{2}, \mathrm{~B}_{3}$ (nicotinamide), $\mathrm{B}_{5}, \mathrm{~B}_{6}$ (pyridoxamine), $\mathrm{B}_{9}, \mathrm{~A}$ (retinol), and $\mathrm{E}$ ( $\alpha$-tocopherol) were simultaneously extracted and detected in blood serum in $<30 \mathrm{~min}$. Previously published methods have not demonstrated simultaneous extraction and detection of these vitamins from biological samples. The combined method presented herein optimized extraction solvents combined with tuned LC properties such as column, ternary mobile phase, and eluent modifiers to produce sufficient sensitivity and peak resolutions that are consistent or better than separate methods. Also, isotopically labeled versions of the target analytes utilized as IS reduced sample preparation errors and compensated for matrix effects and recoveries.

Compared to separate methods for water-soluble and fatsoluble vitamins, our combined method decreased instrument preparation and run time, reduced active technician time by a factor of 5, reduced material and chemical demands, and reduced sample demands. Sample preparation time was also shortened as a single extraction step efficiently extracted both water-soluble and fat-soluble vitamins. This combined method is highly beneficial for applications with limited availability of samples (e.g., infant tears; elderly anemic blood) or sampling small subjects (e.g., rodents). Furthermore, this combined method detects all but one of the critical water-soluble and fatsoluble vitamins for clinical screening and provides substantial time and resource savings for nutritional assessments from biofluids.

\section{Acknowledgments}

The authors would like to thank David T. Burke, from the University of Michigan's Human Genetic Department, for his contribution to the project. This study was supported by the Gerber Foundation (http://www.gerberfoundation.org).

\section{Notation}

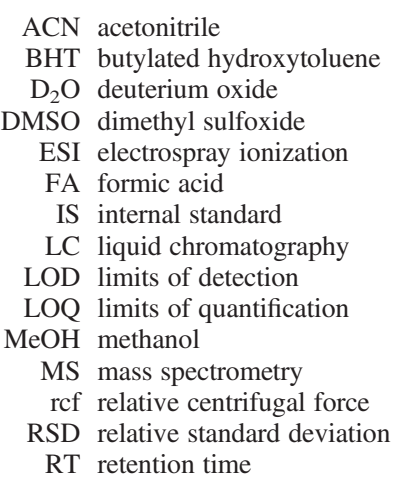

\section{Literature Cited}

1. Phinney KW, Rimmer CA, Thomas JB, Sander LC, Sharpless KE, Wise SA. Isotope dilution liquid chromatography-mass spectrometry methods for fat- and water-soluble vitamins in nutritional formulations. Anal Chem. 2010;83(1):92-98.

2. Ball GFM. Vitamins: Their Role in the Human Body. Ames, IA: Blackwell Science; 2004.

3. Crooke A, Guzman-Aranguez A, Peral A, Abdurrahman MKA, Pintor J. Nucleotides in ocular secretions: their role in ocular physiology. Pharmacol Ther. 2008;119(1):55-73.

4. Kaufman HE. The Cornea. New York, NY: Churchill Livingstone; 1998:1104.

5. Khaksari M, Mazzoleni LR, Ruan C, Kennedy RT, Minerick AR. Determination of water-soluble and fat-soluble vitamins in tears and blood serum of infants and parents by liquid chromatography/mass spectrometry. Exp Eye Res. 2017;155:54-63.

6. Khaksari M, Mazzoleni LR, Ruan C, Kennedy RT, Minerick AR. Data representing two separate LC-MS methods for detection and quantification of water-soluble and fat-soluble vitamins in tears and blood serum. Data Brief. 2017;11:316-330.

7. Lu B, Ren Y, Huang B, Liao W, Cai Z, Tie X. Simultaneous determination of four water-soluble vitamins in fortified infant foods by ultraperformance liquid chromatography coupled with triple quadrupole mass spectrometry. J Chromatogr Sci. 2008;46(3):225-232.

8. Ekinci R, Kadakal Ç. Determination of seven water-soluble vitamins in Tarhana, a traditional Turkish cereal food, by high-performance liquid chromatography. Acta Chromatogr. 2005;15:289-297.

9. Chen Z, Chen B, Yao S. High-performance liquid chromatography/electrospray ionization-mass spectrometry for simultaneous determination of taurine and 10 water-soluble vitamins in multivitamin tablets. Anal Chim Acta. 2006;569(1-2):169-175.

10. Chatzimichalakis PF, Samanidou VF, Verpoorte R, Papadoyannis IN. Development of a validated HPLC method for the determination of Bcomplex vitamins in pharmaceuticals and biological fluids after solid phase extraction. J Sep Sci. 2004;27(14):1181-1188.

11. Goldschmidt RJ, Wolf WR. Simultaneous determination of watersoluble vitamins in SRM 1849 infant/adult nutritional formula powder by liquid chromatography-isotope dilution mass spectrometry. Anal Bioanal Chem. May 2010;397(2):471-481.

12. Priego Capote F, Jimenez JR, Granados JM, de Castro MD. Identification and determination of fat-soluble vitamins and metabolites in human serum by liquid chromatography/triple quadrupole mass spectrometry with multiple reaction monitoring. Rapid Commun Mass Spectrom. 2007;21(11):1745-1754.

13. Wang L-H, Huang S-H. Determination of vitamins A, D, E, and $\mathrm{K}$ in human and bovine serum, and $\beta$-carotene and vitamin A palmitate in cosmetic and pharmaceutical products, by isocratic HPLC. Chromatographia. 2002;55(5):289-296.

14. Blanco D, Fernandez MP, Gutierrez MD. Simultaneous determination of fat-soluble vitamins and provitamins in dairy products by liquid chromatography with a narrow-bore column. Analyst. 2000;125(3):427-431.

15. Delgado Zamarreño MM, Sánchez Pérez A, Gómez Pérez C, Hernández Méndez J. High-performance liquid chromatography with electrochemical detection for the simultaneous determination of vitamin A, D3 and E in milk. J Chromatogr A. 1992;623(1):69-74.

16. Scalia S, Ruberto G, Bonina F. Determination of vitamin A, vitamin E, and their esters in tablet preparations using supercriticalfluid extraction and HPLC. J Pharm Sci. 1995;84(4):433-436.

17. Midttun O, Ueland PM. Determination of vitamins A, D and E in a small volume of human plasma by a high-throughput method based on liquid chromatography/tandem mass spectrometry. Rapid Commun Mass Spectrom. 2011;25(14):1942-1948.

18. Küçükbay FZ, Açari iK. Simultaneous determination of water and fatsoluble vitamins in Pekmez samples by high performance liquid chromatography coupled with diode array detection. Asian J Chem. 2010; 22(5):4083-4091.

19. Midttun O, McCann A, Aarseth O, et al. Combined measurement of 6 fat-soluble vitamins and 26 water-soluble functional vitamin markers and amino acids in $50 \mu \mathrm{L}$ of serum or plasma by high-throughput mass spectrometry. Anal Chem. 2016;88(21):10427-10436.

20. Klejdus B, Petrlová J, Potěšil D, et al. Simultaneous determination of water- and fat-soluble vitamins in pharmaceutical preparations by high-performance liquid chromatography coupled with diode array detection. Anal Chim Acta. 2004;520(1-2):57-67.

21. Eiff J, Monakhova YB, Diehl BWK. Multicomponent analysis of fat- and water-soluble vitamins and auxiliary substances in 
multivitamin preparations by qNMR. J Agric Food Chem. 2015; 63(12):3135-3143.

22. Monakhova YB, Mushtakova SP, Kolesnikova SS, Astakhov SA. Chemometrics-assisted spectrophotometric method for simultaneous determination of vitamins in complex mixtures. Anal Bioanal Chem. 2010; 397(3):1297-1306.

23. Svidritskii EP, Pashkova EB, Pirogov AV, Shpigun OA. Simultaneous determination of fat- and water-soluble vitamins by microemulsion electrokinetic chromatography. J Anal Chem. 2010;65(3):287-292.

24. Santos J, Mendiola JA, Oliveira MBPP, Ibáñez E, Herrero M. Sequential determination of fat- and water-soluble vitamins in green leafy vegetables during storage. J Chromatogr A. 2012;1261:179-188.

25. Tayade AB, Dhar P, Kumar J, Sharma M, Chaurasia OP, Srivastava RB. Sequential determination of fat- and water-soluble vitamins in Rhodiola imbricata root from trans-Himalaya with rapid resolution liquid chromatography/tandem mass spectrometry. Anal Chim Acta. 2013;789:65-73.

26. Mendiola JA, Marin FR, Señoráns FJ, et al. Profiling of different bioactive compounds in functional drinks by high-performance liquid chromatography. J Chromatogr A. 2008;1188(2):234-241.

27. Ferreiro-Vera C, Priego-Capote F, Luque de Castro MD. An approach for quantitative analysis of vitamins D and B9 and their metabolites in human biofluids by on-line orthogonal sample preparation and sequential mass spectrometry detection. Analyst. 2013; 138(7):2146-2155

28. Taguchi K, Fukusaki E, Bamba T. Simultaneous analysis for waterand fat-soluble vitamins by a novel single chromatography technique unifying supercritical fluid chromatography and liquid chromatography. J Chromatogr A. 2014;1362:270-277.

29. Van Agtmaal EJ, Bloem MW, Speek AJ, Saowakontha S, Schreurs WHP, Vanhaeringen NJ. The effect of vitamin-A supplementation on tear fluid retinol levels of marginally nourished preschoolchildren. Curr Eye Res 1988;7(1):43-48.

30. Van Agtmaal EJ, Bloem MW, Speek AJ, Saowakontha S, Van Hearingen NJ, Schreurs WHP. Effect of vitamin A supplements on the retinol in tear fluid. Voeding (The Hague). 1989;50(6-7):198-199.

31. Lin Y, Ubels JL, Schotanus MP, et al. Enhancement of vitamin D metabolites in the eye following vitamin D3 supplementation and UVB irradiation. Curr Eye Res. 2012;37(10):871-878.

32. Paterson CA, O'Rourke MC. Vitamin C levels in human tears. Arch Ophthalmol. 1987;105(3):376-377.

33. Venkata SJA, Narayanasamy A, Srinivasan V, et al. Tear ascorbic acid levels and the total antioxidant status in contact lens wearers: a pilot study. Indian J Ophthalmol. 2009;57(4):289-292.

34. Mayo Clinic. https://www.mayomedicallaboratories.com/test-catalog [last accessed May 29, 2018].

35. National Health and Nutrition Examination Survey (NHANES) Laboratory Data. https://wwwn.cdc.gov/nchs/nhanes/search/datapage.aspx? Component=Laboratory. Accessed May 29, 2018.

36. Lu J, Frank EL. Rapid HPLC measurement of thiamine and its phosphate esters in whole blood. Clin Chem. 2008;54(5):901-906.

37. Khaksari M. Rapid nutritional analysis from infant tears $[\mathrm{PhD}$ Dissertation]. ProQuest: Chemical Engineering, Michigan Technological Unversity; 2016.
38. Harris DC. Quantitative Chemical Analysis. 8th ed. New York, NY: W. H. Freeman and Company; 2010.

39. Rentel C, Strohschein S, Albert K, Bayer E. Silver-plated vitamins: a method of detecting tocopherols and carotenoids in LC/ESI-MS coupling. Anal Chem. Oct 15 1998;70(20):4394-4400.

40. Montero O, Ramirez M, Sanchez-Guijo A, Gonzalez C. Determination of lipoic acid, Trolox methyl ether and tocopherols in human plasma by liquid-chromatography and ion-trap tandem mass spectrometry. Biomed Chromatogr. 2012;26(10):1228-1233.

41. Hampel D, York ER, Allen LH. Ultra-performance liquid chromatography tandem mass-spectrometry (UPLC-MS/MS) for the rapid, simultaneous analysis of thiamin, riboflavin, flavin adenine dinucleotide, nicotinamide and pyridoxal in human milk. J Chromatogr B Analyt Technol Biomed Life Sci. 2012;903:7-13.

42. Rogatsky E, Jayatillake H, Goswami G, Tomuta V, Stein D. Sensitive LC MS quantitative analysis of carbohydrates by Cs+ attachment. $J$ Am Soc Mass Spectrom. 2005;16(11):1805-1811.

43. Van Meulebroek L, Vanhaecke L, De Swaef T, Steppe K, De Brabander H. U-HPLC-MS/MS to quantify liposoluble antioxidants in red-ripe tomatoes, grown under different salt stress levels. J Agric Food Chem 2012;60(2):566-573.

44. Lauridsen C, Leonard SW, Griffin DA, Liebler DC, McClure TD, Traber MG. Quantitative analysis by liquid chromatography-tandem mass spectrometry of deuterium-labeled and unlabeled vitamin $\mathrm{E}$ in biological samples. Anal Biochem. 2001;289(1):89-95.

45. Mayo Clinic. https://www.mayomedicallaboratories.com/test-catalog/ Overview/9198. Accessed April 9, 2018.

46. Fairbanks V, Klee G. Biochemical aspects of hematology. In: Burtis CA, Ashwood ER, eds. Tietz Textbook of Clinical Chemistry. Philadelphia: WB Saunders Company; 1999:1690-1698.

47. Johnson LE. Vitamin Deficiency, Dependency, and Toxicity. Merck Manual for Health Care Professionals. Kenilworth, NJ: Merck Sharp \& Dohme Corporation https://www.merckmanuals.com/ professional, Accessed: May 23, 2016.

48. Baker H. Assessment of biotin status: clinical implications. Ann NY Acad Sci. 1985;447(1):129-132.

49. Vogeser M, Kyriatsoulis A, Huber E, Kobold U. Candidate reference method for the quantification of circulating 25-hydroxyvitamin D3 by liquid chromatography-tandem mass spectrometry. Clin Chem. 2004;50(8): 1415-1417.

50. McClain CJ, Baker H, Onstad GR. Biotin deficiency in an adult during home parenteral nutrition. JAMA. 1982;247(22):3116-3117.

51. Lippi G, Franchini M. Vitamin K in neonates: facts and myths. Blood Transfus. 2011;9(1):4-9.

52. Saenger AK, Laha TJ, Bremner DE, Sadrzadeh SM. Quantification of serum 25-hydroxyvitamin $\mathrm{D}(2)$ and $\mathrm{D}(3)$ using HPLC-tandem mass spectrometry and examination of reference intervals for diagnosis of vitamin D deficiency. Am J Clin Pathol. 2006;125(6):914-920.

53. Papadoyannis IN, Tsioni GK, Samanidou VF. Simultaneous determination of nine water and fat soluble vitamins after SPE separation and RP-HPLC analysis in pharmaceutical preparations and biological fluids. J Liq Chromatogr Relat Technol. 1997;20(19):3203-3231.

Manuscript received Feb. 7, 2018, and revision received May 30, 2018. 